\title{
Sterol carrier protein- $x$ gene and effects of sterol carrier protein-2 inhibitors on lipid uptake in Manduca sexta
}

\author{
Min-Sik Kim ${ }^{1}$ and Que Lan*2
}

\begin{abstract}
Background: Cholesterol uptake and transportation during the feeding larval stages are critical processes in insects because they are auxotrophic for exogenous (dietary) cholesterol. The midgut is the main site for cholesterol uptake in many insects. However, the molecular mechanism by which dietary cholesterol is digested and absorbed within the midgut and then released into the hemolymph for transportation to utilization or storage sites is poorly understood. Sterol carrier proteins (SCP), non-specific lipid transfer proteins, have been speculated to be involved in intracellular cholesterol transfer and metabolism in vertebrates. Based on the high degree of homology in the conserved sterol transfer domain to rat and human SCP-2, it is supposed that insect SCP-2 has a parallel function to vertebrate SCP-2.

Results: We identified the Manduca sexta sterol carrier protein- $x$ and the sterol carrier protein-2 (MsSCP-x/SCP-2) gene from the larval fat body and the midgut CDNAs. The MsSCP-X/SCP-2 protein has a high degree of homology in the SCP2 domain to other insects' SCP-2. Transcripts of MsSCP-2 were detected at high levels in the midgut and the fat body of M. sexta during the larval stages. Recombinant MsSCP-2 bound to NBD-cholesterol with high affinity, which was suppressed by sterol carrier protein-2 inhibitors.
\end{abstract}

Conclusions: The results suggest that MsSCP-2 may function as a lipid carrier protein in vivo, and targeting insect SCP2 may be a viable approach for the development of new insecticides.

\section{Background}

In insects, cholesterol is required as a structural component of cellular membranes and as a precursor for the insect molting hormone (ecdysone). However, insects lack several enzymes in the cholesterol biosynthesis pathway [1], which makes them auxotrophic for exogenous (dietary) cholesterol for satisfactory growth, development and reproduction [2-4]. Therefore, cholesterol uptake and transportation are critical for their survival. Uptake of cholesterol involves intracellular transfer and intercellular transportation. Intracellular cholesterol transfer enables the redistribution of cholesterol within a cell, and intercellular transport is needed for the distribution of cholesterol between cells. It is very well documented that lipophorin (Lp) and lipid transport particles (LTPs) are

* Correspondence: qlan@entomology.wisc.edu

2 Department of Entomology, University of Wisconsin, 1630 Linden Drive, Madison, WI 53706, USA

Full list of author information is available at the end of the article responsible for the intercellular transportation of cholesterol and lipids in insects [5-7].

Cholesterol is highly hydrophobic with solubility of $\sim 10$ $\mathrm{nM}$ in water at room temperature [8], can be easily inserted into the lipid bilayer and has a fast flip-flop rate $\left(t_{1 / 2}=1-2\right.$ minutes $)$ within the lipid bilayer [9]. Diffusion of cholesterol into the lipid bilayer can happen readily, and an aqueous diffusion model has been proposed to account for some of the cholesterol uptake by cells [10]. However, the desorption of membrane-bound cholesterol is slow without the aid of a carrier protein $[10,11]$ to enhance the desorption of membrane-bound cholesterol through the collision with membrane-bound cholesterol [12]. In vertebrates, sterol carrier protein-2 increases the rate of cholesterol transfer between membrane structures from $\mathrm{t}_{1 / 2}=4$ days to $\mathrm{t}_{1 / 2}=7-15$ minutes in vitro [11], demonstrating the potential of lipid carrier proteins to enhance cellular lipid uptake. 
Insect cells do not transfer cholesterol between the midgut and the fat body via receptor mediated endocytosis of Lp. The diffusion of cholesterol from Lp to target cell membranes is thought to be the main mechanism for the transport of cholesterol to cells [13]. Moreover, Lp is the only apolipoprotein found in insects and Lp is not synthesized in the midgut $[14,15]$, which excludes the possibility of efflux of absorbed lipids from the midgut into the hemolymph via exocytosis of apolipoprotein/ lipid vehicles $[7,16]$. Therefore, nonvesicular transport of intracellular cholesterol may be important in insect cellular cholesterol uptake via intracellular sterol carrier protein(s) to aid the desorption of membrane-bound cholesterol and the delivery of the cholesterol within the cytosol.

Little is known about the protein(s) involved in the intracellular transfer of cholesterol in insects. Several insect intracellular sterol carrier protein genes have been identified such as the sterol carrier protein- $x$ [17-19], the sterol carrier protein-2 [20], and the steroid acute regulator protein (StAR)-related lipid transfer protein [21,22]. In most cases, the function of those insect intracellular sterol carrier proteins is deduced from the temporal and spatial expression profiles and from the known function of their vertebrate homologs.

Genomic sequence data show that insects may have multiple copies of sterol carrier protein-2 (SCP-2)-like proteins $[18,23,24]$, in contrast to the single copy of the SCP-x/SCP-2 gene in vertebrates $[25,26]$ and in the silkworm, B. mori [27]. SCP-x belongs to the SCP-2 gene family, which includes SCP-2, SCP-x, 17 $\beta$-hydroxysteroid dehydrogenase IV, UNC-24, Metallo- $\beta$-lactomase and stomatin $[26,28]$. In vertebrates, the SCP-x/SCP-2 gene has two initiation sites for coding proteins. One site codes for SCP-x which is post-translationally cleaved into 2/3oxoacyl-CoA thiolase and SCP-2. A second site codes for SCP-2. Both SCP-x and SCP-2 share a common SCP-2 Cterminus. Increasingly, data suggest that 3-oxoacyl-CoA thiolase is involved in the oxidation of branched chain fatty acids and SCP-2 is involved in the transfer of lipids $[29,30]$. Whether insect SCP-2 and SCP-2-like proteins have similar or divergent functions is unknown. Some insect SCP-2 and SCP-2-like proteins lack the peroxisome targeting sequence at the $\mathrm{C}$-termini, suggesting that they are cytosolic proteins [23,31]. AeSCP-2, an Aedes aegypti SCP-2 protein which is not produced from the SCP-x gene, binds to both cholesterol [20] and fatty acid [32], which is consistent with the broad spectrum of lipid ligands of the vertebrate SCP-2. Over-expression or knockdown of AeSCP-2 gene expression affects cholesterol uptake in vivo [23,31,33]. Chemical inhibitors of AeSCP-2 suppress cholesterol uptake in cultured cells from Aedes aegypti and Manduca sexta, indicating that M. sexta has a protein homologous to AeSCP-2 [34]. The tobacco hornworm, Manduca sexta, has been one of the primary experimental insect model systems for sterol metabolism studies [35]. Studies using M. sexta have contributed to a broad picture of lipid metabolism and have revealed that cholesterol is transported from the midgut to the fat body via lipophorin (Lp) in the hemolymph in the free form, and absorbed cholesterol is stored as cholesterol ester

Here, we report molecular cloning and characterization of cDNA encoding SCP-x and SCP-2 from the tobacco hornworm (Manduca sexta), and the effect of sterol carrier protein-2 inhibitors (SCPIs) on cholesterol and fatty acid uptake in $M$. sexta larvae. The results suggest that MsSCP-x/SCP-2 is involved in cholesterol absorption and transportation in insects.

\section{Results \\ Molecular cloning and nucleotide sequence analysis of MsSCP-x/SCP-2}

A PCR-based cloning strategy was used to clone the MsSCP-x/SCP-2 gene, using cDNAs from the larval midgut and fat body as templates. Degenerate primers (MsSCP-CF1 and MsSCP-CR1) allowed us to obtain a cDNA fragment highly homologous to the SCP-2 domain of BmSCP-x and SISCP-2 (Table 1). The degenerated primer $\mathrm{xNF}$ and gene specific primer CR2 produced a cDNA fragment of about $1100 \mathrm{bp}$, which matches the 2/ 3-oxoacyl-CoA thiolase domain of insect SCP-x. The 3'RACE using MsSCP-CF3 primer (Fig. 1) produced independent cDNA clones of about 550 bp containing a putative translation stop site (Fig. 1). Additional gene specific primers (MsSCP-CR4: 5'-TGG CAA GGT GCA CCT CTG-3' and MsSCP-CR3: 5'-AGA ACT AGA ACG GGA CCT TC-3') derived from partial MsSCP-x cDNA sequence were synthesized and used for the $5^{\prime}$-RACE to obtain the 5 '-ends of the cDNA. The 5'-RACE using CR4 primer produced cDNA clones of 553 bp containing a putative translation start site at position 39 (Fig. 1). All results taken together indicate that a putative full-length MsSCP-x/SCP-2 gene spans a total of 1918 bps and encodes a protein of 536 amino acids (GQ869536). Interestingly, 6 independent cDNA clones from the CR3 primer 5'-RACE had $46 \mathrm{bp}$ sequences at the 5 '-end divergent from the MsSCP-x (Fig. 1 gray colored shaded sequence), suggesting that the MsSCP-2 transcript (GQ869537) may be made from alternative splicing or an alternative initiation site. The deduced amino acid sequence of the coding region showed high similarity to members of the SCP-2 gene family in other insect species (Table 1). The SCP-2 domain of Manduca SCP-x has amino acid sequence identities of $97 \%, 93 \%, 79 \%, 69 \%$, and 69\% with Bombyx mori, Spodoptera littoralis, Aedes aegypti, Apis melifera, and Drosophila melanogaster, respectively (Table 1 ). The MsSCP-x/SCP-2 gene encodes 
Table 1: Identities of deduced amino acid sequences of the MsSCP-x/SCP-2 (Accession\# GQ869536 and GQ869537) to the proteins of insect SCP-x gene in other insect species

\begin{tabular}{cccc}
\hline & SCP-x & 2/3-oxoacyl-CoA-thiolase domain & SCP-2 domain \\
\hline Bombyx mori & $91.79 \%$ & $90.48 \%$ & $96.55 \%$ \\
Spodoptera littoralis & $89.37 \%$ & $88.33 \%$ & $93.10 \%$ \\
Drosophila melanogaster & $61.88 \%$ & $60.57 \%$ & $68.64 \%$ \\
Apis melifera & $60.81 \%$ & $59.29 \%$ & $68.97 \%$ \\
Aedes aegypti & $64.51 \%$ & $60.71 \%$ & $78.45 \%$ \\
Aedes aegypti (AeSCP-2) & & & $23.47 \%$ \\
\hline
\end{tabular}

the SCP-x protein with much higher homology to BmSCP-x and SISCP-x than the Dipteran SCP-x such as AeSCP-x and DmSCP-x (Table 1).

\section{Tissue and stage expression profiles of MsSCP-x/SCP-2}

The transcription profiles of MsSCP-2 in different tissues and stages were determined by semi-quantitative RTPCR. The MsSCP-2 mRNA level was significantly higher in the midgut and fat body in feeding larvae (Fig. 2A, upper panel for midgut lanes A-D). MsSCP-2 was strongly expressed throughout the examined larval stages and decreased slightly in the wandering and pupal stages (Fig. 2A, upper panel for midgut lane E-F). In the fat body, there was a transient increase in MsSCP-2 transcripts at the end and beginning of each instar (Fig. 2A, upper panel for fat body lanes B-C). Low levels of MsSCP-2 mRNA were detected in the hemolymph, hindgut, epidermis and muscle (Fig. 2A). However, primers corresponding to the 2/3-oxoacyl-CoA thiolase domain detected MsSCP-x mRNA at moderate and high levels in all tissues except the midgut (Fig. 2A, lower panel for midgut lanes A-F). Data from RT-PCRs showed that the transcription of SCP-x and SCP-2 mRNAs from the MsSCP-x/SCP-2 gene is regulated differently in different tissues. MsSCP-2 mRNA was the predominant transcript from this gene in the midgut during the feeding stage (Fig. 2A, midgut, lanes A-D). In the midgut, the levels of MsSCP-2 transcript increased during the $5^{\text {th }}$ larval instar without any increase in the level of MsSCP-x transcript (Fig. 2A, midgut, lanes C-D). This result implies that the MsSCP-x/SCP-2 gene might produce two transcripts: SCP-x mRNA and SCP-2 mRNA, which is similar to the human SCP-x/SCP-2 gene and other lepidopteran SCP-x/SCP-2, BmSCP-x/BmSCP-2 [26,27].

Western blotting analysis was performed to investigate the existence of an SCP-2 homolog in tissues from Day 3 $4^{\text {th }}$ instars using affinity-purified anti-SCP-2 domain polyclonal antibodies of mosquito SCP-x, AeSCP-x [31]. Figure 3 shows that a protein similar to the molecular weight of $14 \mathrm{kDa}$ (the predicated molecular weight of MsSCP-2 is $14,134 \mathrm{Da}$ ) was detected by anti-AeSCP-x antibodies, suggesting that $M$. sexta may have a SCP-2 analog. Tissues expressing MsSCP-2 in M. sexta at high levels were the midgut and fat body, which was consistent with the results of RT-PCR (Fig. 2A, lane B). Trace amounts of SCP-2 were also detected in the hindgut and epidermis (Fig. 2B, lane 4 and 7). A band of about $58 \mathrm{kDa}$ protein in the hemolymph was detected by the anti-SCP2 domain antibody, which was presumably the full-length MsSCP-x. In both the hindgut and epidermis, the predominant transcript from the MsSCP-x/SCP-2 gene was the SCP-x mRNA (Fig. 2A, lane B), whereas the MsSCP-2 protein was the only detectable product of the MsSCP-x/ 2 gene (Fig. 2B, lanes 4 and 7). The results indicate that the full length MsSCP-x protein was proteolytically cleaved to produce the SCP-2 domain protein in those tissues. The MsSCP-x protein was not processed to produce MsSCP-2 in the hemocytes due to the prominent $\mathrm{SCP}-\mathrm{x}$ band and the lack of the MsSCP-2 band (Fig. 2B, lane 2).

\section{Ligand and SCPIs binding in MsSCP-2}

The binding affinity $\left(K_{d}\right)$ of recombinant MsSCP-2 to the cholesterol analog was determined using an NBD-cholesterol binding assay. As shown in Figure 4, increasing the concentrations of MsSCP-2 (over the range $1 \mathrm{nM} \sim 10$ $\mu \mathrm{M})$ while maintaining the concentration of NBD-cholesterol constant $(1 \mu \mathrm{M})$ resulted in increased fluorescence emission of NBD-cholesterol. Analysis of the binding curve using the one site binding non-linear regression model in GraphPad PRISM software (Ver. 4.0) yielded high binding affinity for both MsSCP-2 and AeSCP-2 (positive control). Aedes aegypti SCP-2 (AeSCP-2) is not transcribed from the SCP-x gene [18] but belongs to the SCP-2 gene family, and has been shown to have high affinity to cholesterol [20]. The binding affinity $\left(K_{d}\right)$ was $1.86 \times 10^{-6} \mathrm{M}\left(\mathrm{R}^{2}=0.9039\right)$ for MsSCP-2 and $8.2 \times 10^{-7} \mathrm{M}$ $\left(\mathrm{R}^{2}=0.9231\right)$ for AeSCP-2, respectively. However, the GST (negative control) showed little binding to NBDcholesterol (Fig. 3, GST). Although Scatchard plots are useful for visualizing data, they are not the most accurate estimation. In this experiment, we used the one site bind- 


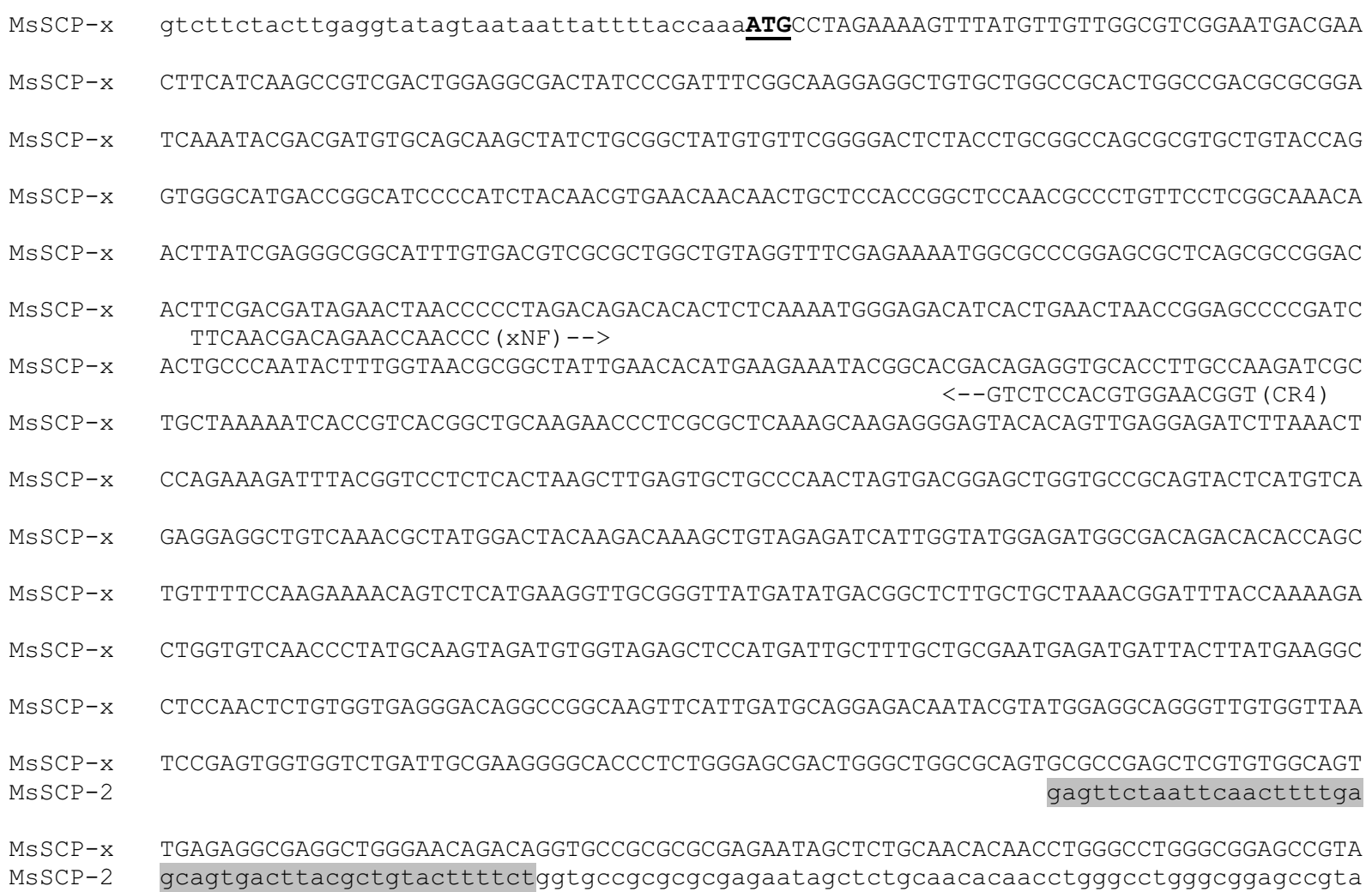

MsSCP-x GTCATCACGATGTACAGGAAAGGATTCACCAATGTCAGCCCCAACAACGTGGCCGCCATCGCTAGCAGCCCCGAGGAGTT MsSCP-2

MSSCP-x MSSCP-2

MSSCP-X MsSCP -2

MSSCP-x MsSCP-2

$\operatorname{MSSCP}-\mathrm{x}$ MSSCP-2

MSSCP-X MSSCP-2

MsSCP-X MsSCP-2

MSSCP $-x$ MsSCP-2

MSSCP-x MSSCP-2 gt catcacgATGTACAGGAAAGGATTCACCAATGTCAGCCCCAACAACGTGGCCGCCATCGCTAGCAGCCCCGAGGAGTT

CAAAGTGTACAAATACATGAAGATCCTCGAGGAGGCGATGCAGACCGACGAGGACAATCTCATCGAGAAGGTGCGCGGCA CAAAGTGTACAAATACATGAAGATCCTCGAGGAGGCGATGCAGACCGACGAGGACAATCTCATCGAGAAGGTGCGCGGCA CAAATACATGAAGATCCTTGA (CF1) -->

TCTACGGGTTCAAGGTCAGGAATGGACCCAACGGTGCTGAGGGTTACTGGGTCATTAATGCCAAGGAAGGCAAAGGGAAA TCTACGGGTTCAAGGTCAGGAATGGACCCAACGGTGCTGAGGGTTACTGGGTCATTAATGCCAAGGAAGGCAAAGGGAAA TACGGGTTCAAGGTCAGGAATGGA (CF2) -->

GTCACCTACAATGGCAGCGAGAAACCCGACGTCACTTTCACAGTGAGCGATGAAGATGTCGCTGATCTGATCTCCGGCAA GTCACCTACAATGGCAGCGAGAAACCCGACGTCACTTTCACAGTGAGCGATGAAGATGTCGCTGATCTGATCTCCGGCAA AAACCCGACGTCACTTTCAC ( $\mathrm{CF} 3)-->$

GCTGAACCCGCAGAAGGCGTTCTTCCAGGGCAAGATCAAGATCCAGGGCAACATGGGCCTGGCGATGAAGCTCACGGACC GCTGAACCCGCAGAAGGCGTTCTTCCAGGGCAAGATCAAGATCCAGGGCAACATGGGCCTGGCGATGAAGCTCACGGACC $<--($ CR3) GAAGGTCCCGTTCTAGTTCTAGGTC $<--($ CR2 ) CCGTTCTAGTTCTAGGTCCCGTT

TGCAGAGACAAGCCGCTGGCAGGATTGACACCATCCGCTCCAAACTGTAGactccaaaccggttgcgaactggttgtaat TGCAGAGACAAGCCGCTGGCAGGATTGACACCATCCGCTCCAAACT GTAGactccaaaccggttgcgaactggttgtaat $<--(\mathrm{CR} 1)$ GTTCGGCGGCCGTCCTAGCT

gtaatttggttacggaacgcggtgtgggcatctttatacttaatcgcacatgaaatagttacatcggcaacctgttggtg gtaatttggttacggaacgcggtgtgggcatctttatacttaatcgcacatgaaatagttacatcggcaacctgttggtg

tttttataatgtaaacataaacaaggtcacacacgtttgggagtggacgtgctataagtgttttgtatgtaagtgtaaa ttttataatgtaaacataaacaaggtcacacacgtttgggagtggacgtgctataagtgttttgtatgtaagtgtaaa

tcgtttatattgtataatatatttatgtaatcattccaatgtttattcatatttgttaataaatatttttatatga tcgttttatattgtataatatatttatgtaatcattccaaatgtttattcatatttgttaataaatattttttatatga

Figure 1 The nucleotide sequences of MsSCP-x (GQ869536) and MsSCP-2 (GQ869537) cDNAs. The start and stop codons are bold/underlined. The divergent 5' UTR sequence in MsSCP-2 is in shaded in gray color. Potential intron/exon splicing site in the MsSCP-2 5'UTR is in bold lower case letter. Sequences of forward and reverse primers used in cloning and RT-PCR are aligned under the CDNA sequence with arrows indicating the orientation for $P C R$ reactions. 


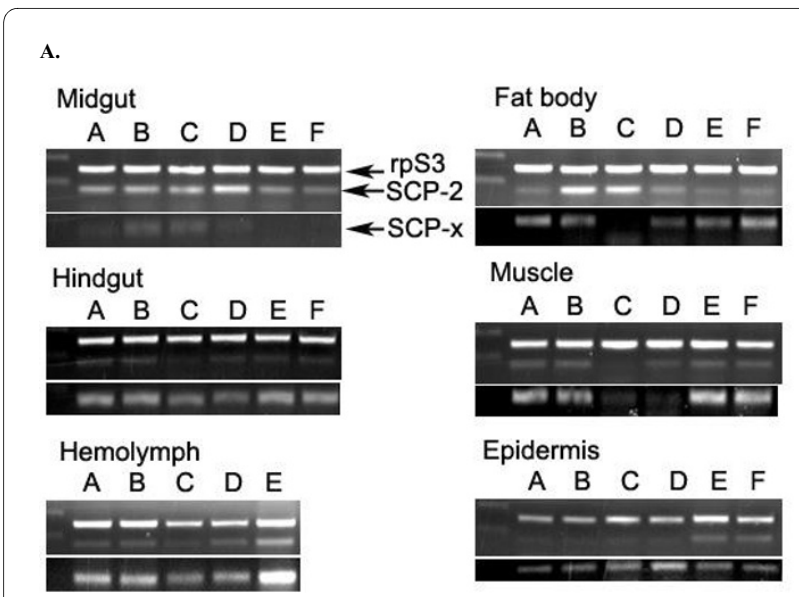

B.

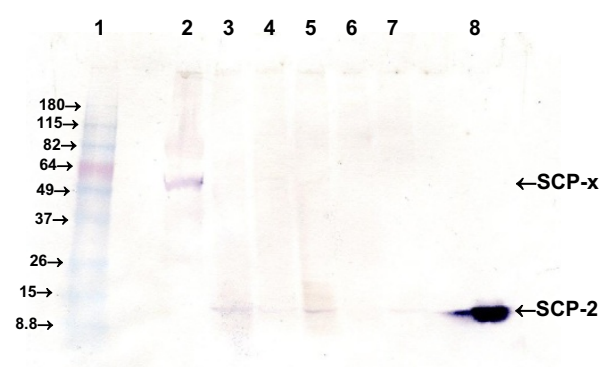

Figure 2 Expression of MsSCP-x and MsSCP-2. (A) The semi-quantitative RT-PCR shows that $m R N A$ levels from different tissues at different developmental stages of $M$. sexta. Lane A: Day $1-4^{\text {th }}$ instar; lane B: Day 3-4th instar; lane C: Day 1-5th instar; lane D: Day 4-5th instar; lane E: Day 1-wandering stage; lane F: Day 1-pupal stage. The Manduca rpS3 gene was used as internal standard for the RT-PCR. Only 30 cycles of PCR were performed to avoid saturating the signals. (B). Proteins from different tissues of Day 3-4th instar M. sexta larva were loaded $20 \mu \mathrm{g}$ per lane except lane 8 that only had 10 ng purified recombinant MsSCP-2. Protein was analyzed on 4-20\% gradient SDS PAGE. Lane 1: protein size marker; Lane 2: hemolymph; Lane 3: midgut; Lane 4: hindgut; Lane 5: fat body; Lane 6: muscle; Lane 7: epidermis; Lane 8: recombinant MsSCP-2.

ing non-linear regression model, since the linear transformation of Scatchard plots distorts the experimental error.

The inhibitory effect of SCPIs on cholesterol binding to MsSCP-2 was measured using NBD-cholesterol competition assays. SCPI- 1 and SCPI-2 reduced NBD-cholesterol binding to MsSCP-2 in a concentration-dependent fashion (Fig. 4). AeSCP-2 and GST proteins were used as positive and negative controls, respectively. SCPIs inhibited the binding of NBD-cholesterol to both MsSCP-2 and AeSCP-2. However, SCPIs showed no effect on the binding of NBD-cholesterol and GST, which is a non-binding protein to lipid species (Fig. 4). The $50 \%$ maximal effective concentration $\left(\mathrm{EC}_{50}\right)$ of SCPI-1 and SCPI-2 to block NBD-cholesterol-MsSCP-2 binding was determined

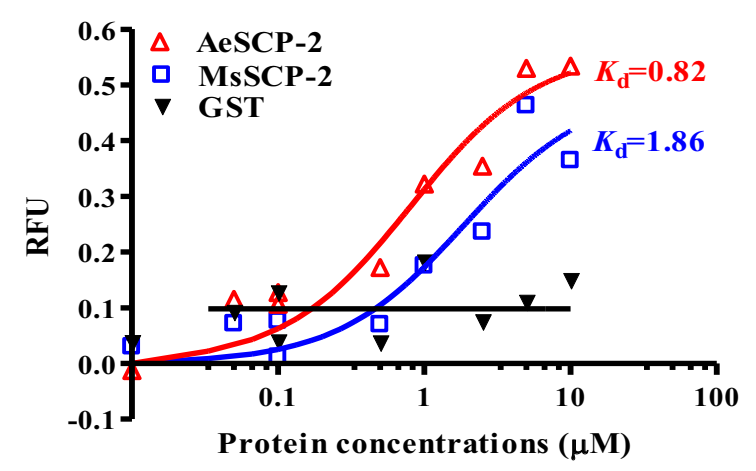

Figure 3 NBD-cholesterol binding assays for MsSCP-2, AeSCP-2 and GST. The data were processed using PRISM4.0 software. RFU = Relative fluorescence unit.

A

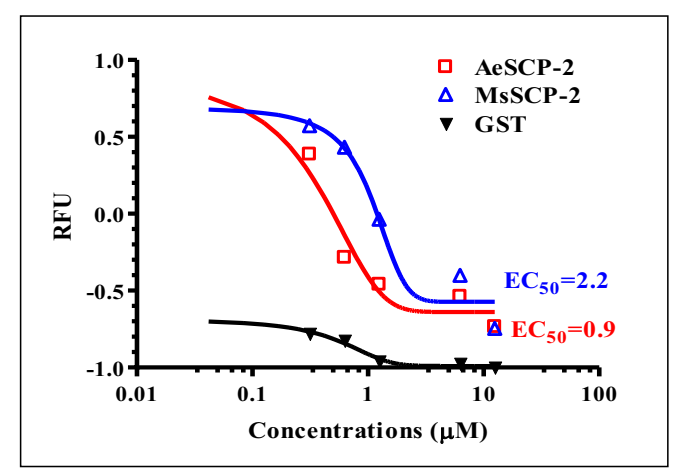

B

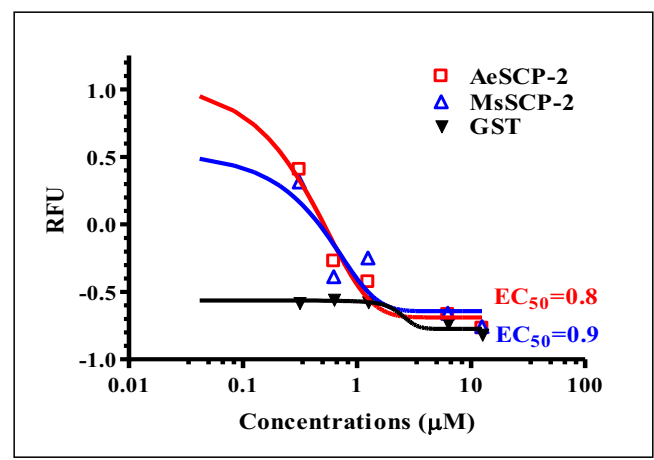

Figure 4 NBD-cholesterol and SCPIs competition binding assays to MsSCP-2. Assays for NBD-cholesterol and sterol carrier protein-2 inhibitors (SCPIs; A: SCPI-1; B: SCPI-2) competitive binding to MsSCP-2. The background NBD-cholesterol fluorescence (NBD-cholesterol alone in the reaction buffer) was deducted from each assay. Shown are net changes in NBD-cholesterol fluorescence in intensity (RFU = Relative fluorescence unit) in the presence of increasing concentrations of each SCPI. GST and AeSCP-2 were used as negative and positive controls, respectively. The data were processed using PRISM4.0 software. 
using the one site competition binding, non-linear regression model in GraphPad PRISM ${ }^{\circ}$ software version 4.0 (GraphPad Software Inc., San Diego, CA). The $\mathrm{EC}_{50} \mathrm{~S}$ of SCPI- 1 were $2.2 \mu \mathrm{M}\left(\mathrm{R}^{2}=0.9531\right)$ and $0.9 \mu \mathrm{M}\left(\mathrm{R}^{2}=\right.$ 0.9801) for MsSCP-2 and AeSCP-2, respectively (Fig. 4A). The $\mathrm{EC}_{50}$ s of SCPI-2 were $0.9 \mu \mathrm{M}\left(\mathrm{R}^{2}=0.8832\right)$ and 0.8 $\mu \mathrm{M}\left(\mathrm{R}^{2}=0.9773\right)$ for MsSCP-2 and AeSCP-2, respectively (Fig. 4B). The result suggests that SCPIs have high binding affinities to insect SCP-2s and are able to compete with NBD-cholesterol for binding to MsSCP-2 and AeSCP-2. The result also indicates that SCPI-2 may be more effective in inhibiting MsSCP-2's function than that of SCPI-1 (Fig. 4), which is consistent with the observation in the mosquito AeSCP-2 [34]. Whether the differences in the $\mathrm{EC}_{50}$ values of SCPI-1 and SCPI-2 in inhibiting cholesterol binding to MsSCP-2 result in different biological effects will be described later.

\section{Effects of SCPIs on lipid uptake in M. sexta}

To determine whether MsSCP-2 is involved in cholesterol uptake in vivo, we investigated the effects of SCPIs on cholesterol absorption in gate II day $34^{\text {th }}$ instar larvae when MsSCP-2 expression was high in both the midgut and fat body (Fig. 2A, lane B). Larvae were fasted for 2 hours, then were fed $0.1 \mathrm{~g}$ of diet containing $\left[1,2-{ }^{3} \mathrm{H}\right]$ cholesterol and SCPI-1 and SCPI-2 at $\mathrm{LD}_{50}$ dosages [34]. Tracking the ingested $\left[1,2-{ }^{3} \mathrm{H}(\mathrm{N})\right]$-cholesterol in Schistocerca gregaria showed that insects appear not to alter the ${ }^{3} \mathrm{H}$ label on the $\left[1,2-{ }^{3} \mathrm{H}\right]$-cholesterol in vivo, therefore, measuring the amount of $\left[1,2-{ }^{3} \mathrm{H}\right]$-cholesterol can be used directly as an indication of cholesterol uptake [36]. Moreover, Manduca sexta larvae absorb free [ $\left.{ }^{3} \mathrm{H}\right]$-cholesterol readily with little modification of the absorbed [1,2$\left.{ }^{3} \mathrm{H}\right]$-cholesterol [37].

The lipophorin in the hemolymph uploads absorbed dietary lipids at the basal side of the midgut and transports the cholesterol to the fat body for storage $[14,16]$. It was hypothesized that cytosolic lipid transport proteins in the midgut transfer absorbed dietary lipids toward the basal side of the epithelium where lipophorin picks up the lipids $[7,16]$. We speculated that MsSCP-2 could be one of the midgut sterol carrier proteins that aid the uptake of cholesterol because MsSCP-2 was expressed at high levels in the midgut and fat body (Fig. 2A and 2B) and MsSCP-2 bound to a cholesterol analog (Fig. 2B). To determine whether the inhibition of MsSCP-2 function would affect cholesterol uptake from the diet into the midgut, $\left[{ }^{3} \mathrm{H}\right]$-cholesterol in midgut tissue was measured at different time points after feeding. In the midgut tissue, $\left[{ }^{3} \mathrm{H}\right]$-cholesterol content decreased significantly in the controls between 2 and 6 hours post feeding ( $p=$ $0.003)$, indicating the clearance of absorbed $\left[{ }^{3} \mathrm{H}\right]$-cholesterol over time from the midgut tissue (Fig. 5A, control).
The result is consistent with the previous report of a slow but steady clearance of $\left[{ }^{3} \mathrm{H}\right]$-cholesterol from the midgut within 6 hours post feeding [37]. In SCPI-1 treated larvae at the 2 hour time point, the total $\left[{ }^{3} \mathrm{H}\right]$-cholesterol in the midgut tissue was slightly lower than that of the control group, whereas, the SCPI-2-treated group had signifi-

A.

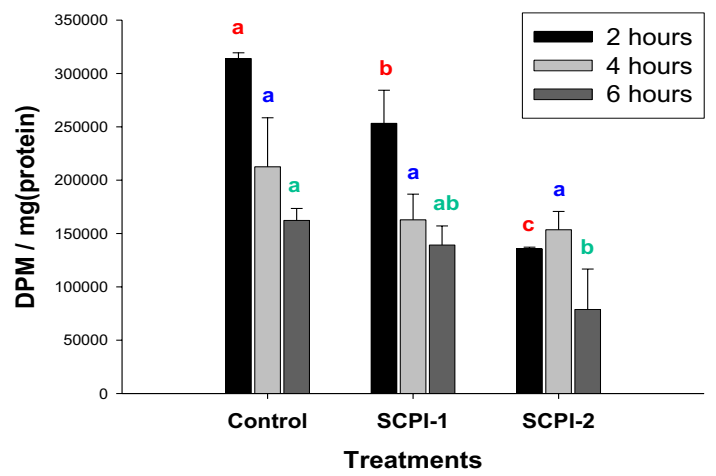

B.

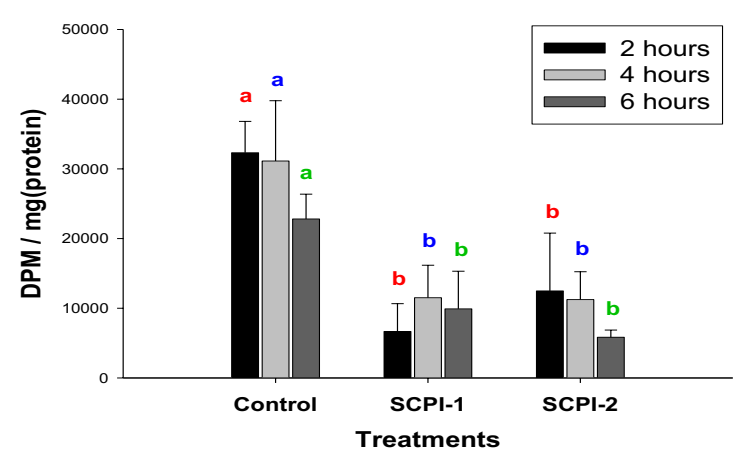

C.

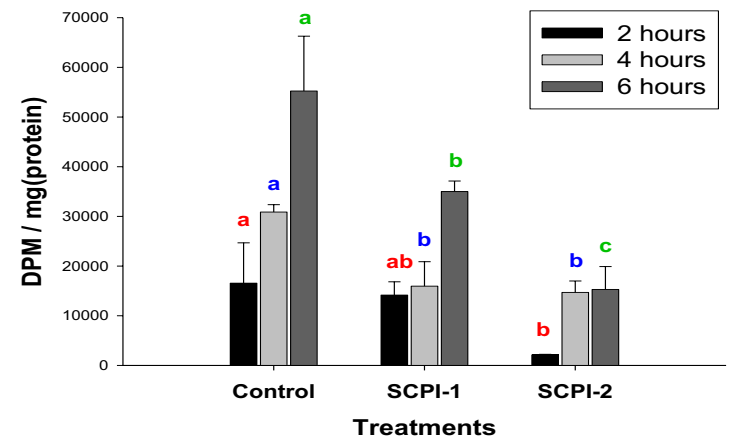

Figure 5 Effects of SCPIs on $\left[1,2-{ }^{3} \mathrm{H}(\mathrm{N})\right]$-cholesterol uptake in $M$. sexta Day $34^{\text {th }}$ instar larvae. (A) The midgut. (B) The hemolymph. (C) The fat body. Values = mean \pm S.D. $(N=2)$. Details of the label/chase experiment are provided in the "Materials and Methods". The same letters above the bars in each time point represent that the mean values did not differ from other group of the same time point significantly ( $p$ $>0.05$ ) in paired t-tests. 
cantly much less ( $p=0.01 ; 43.18 \%$ of the controls) labeled cholesterol (Fig. 5A, 2 hour time point). At 6 hours post feeding, there was a significant decrease of $\left[{ }^{3} \mathrm{H}\right]$-cholesterol in the midgut in both the control and SCPI-1treated groups $(p=0.04)$, indicating that absorbed cholesterol was likely transported out of the midgut tissues (Fig. 5A, 4 hour time point). There was no significant change in the levels of labeled cholesterol 2 to 6 hours post feeding in SCPI-2-treated groups (Fig. 5A, 4 hour time point), which suggests that there was little transfer of absorbed cholesterol. Over the observed time period, the total amount of $\left[{ }^{3} \mathrm{H}\right]$-cholesterol in the midgut tissue was significantly lower in SCPI-1 and SCPI-2-treated larvae than in the controls $\left(F_{1,6}=8.627, p=0.026\right.$ and $F_{1,6}=$ $51.47, p=0.0004$, respectively). The amount of $\left[{ }^{3} \mathrm{H}\right]$-cholesterol in the midgut 2 to 6 hours post feeding was 688640.7, 555098.9, and 367836.9 DMP/mg protein for the control, SCPI-1-, and SCPI-2-treated groups, respectively (Fig. 5A). The results imply that the uptake of $\left[{ }^{3} \mathrm{H}\right]-$ cholesterol into the midgut tissue in SCPI-treated larvae was less efficient than in the controls. SCPI-2 was more effective in inhibiting cholesterol binding to MsSCP-2 than that of SCPI-1 (Fig. 4). SCPI-2 had severer effects on MsSCP-2's function in vivo resulting in a $46 \%$ greater reduction in $\left[{ }^{3} \mathrm{H}\right]$-cholesterol uptake/transport than the SCPI-1-treatment $\left(F_{1,6}=19.55, p=0.0045\right)$ in the midgut tissue (Fig 5A, SCPI-1 and SCPI-2).

To determine whether the inhibition of MsSCP-2 function would affect cholesterol transfer from the midgut to the hemolymph, $\left[{ }^{3} \mathrm{H}\right]$-cholesterol in the hemolymph was measured at different time points after the feeding. In the hemolymph, constant high levels of $\left[{ }^{3} \mathrm{H}\right]$-cholesterol were observed over the time period in the control group (Fig. $5 \mathrm{~B})$, which is consistent with the observation that hemolymph $\left[{ }^{3} \mathrm{H}\right]$-cholesterol levels in the label/chase experiments remains steady 4-18 hours post feeding [38]. However, the hemolymph $\left[{ }^{3} \mathrm{H}\right]$-cholesterol levels were significantly lower $\left(F_{1,6}=38.72, p=0.0008\right.$ and $F_{1,6}=$ $33.15, p=0.0012$ for SCPI-1 and SCPI-2, respectively) in the SCPI-treated groups at all post feeding time points (Fig. 5B, SCPI-1 and -2). The amount of hemolymph $\left[{ }^{3} \mathrm{H}\right]$-cholesterol at each time point was significantly higher in control larvae than that of SCPI-1-treated larvae (Fig. 5B, control and SCPI-1) whereas there were insignificant differences at the same time point in the amount of $\left[{ }^{3} \mathrm{H}\right]$-cholesterol in the midgut tissue between the controls and SCPI-1-treated larvae (Fig. 5A, control and SCPI-1). The results indicate that the efflux of absorbed cholesterol from the midgut into the hemolymph was affected in SCPI-treated larvae, suggesting that there was an impairment of $\left[{ }^{3} \mathrm{H}\right]$-cholesterol transport from the midgut into the hemolymph. On the other hand, the amount of labeled cholesterol in the hemo- lymph 2 to 6 hours post feeding was 28087.6 and 29564.4 $\mathrm{DPM} / \mathrm{mg}$ protein for SCPI-1 and SCPI-2 treated larvae, respectively (Fig. 5B), showing that the efflux of cholesterol from the midgut into the hemolymph was similar between SCPI-1 and SCPI-2 treated larvae even though SCPI-2 treated larvae had significantly lower levels of labeled cholesterol in the midgut (Fig. 5A). Therefore, SCPI-1 and SCPI-2 had a similar effect on the efflux of cholesterol despite the differences in their efficiency in inhibiting cholesterol binding to MsSCP2 (Fig. 4).

The insect fat body is the site of cholesterol storage during the feeding stage [38]. The amount of $\left[{ }^{3} \mathrm{H}\right]$-cholesterol increased 3 -fold from 2 hours to 6 hours post feeding in the fat body of the control larvae, indicating an uptake of $\left[{ }^{3} \mathrm{H}\right]$-cholesterol over time (Fig. 5C, control). The results from the controls are consistent with other studies in which ingested $\left[{ }^{3} \mathrm{H}\right]$-cholesterol is rapidly accumulated in the fat body in Manduca larvae [38]. In contrast, in SCPI-1 or SCPI-2 treated larvae, the accumulation of $\left[{ }^{3} \mathrm{H}\right]$-cholesterol in the fat body within 6 hours post feeding was significantly lower $\left(F_{2,9}=29.64, p\right.$ $=0.0001$ ) than that of in the controls (Fig. $5 \mathrm{C}$, SCPI-1 and SCPI-2). This is consistent with the observation that the total amount of $\left[{ }^{3} \mathrm{H}\right]$-cholesterol is significantly lower in the hemolymph of SCPI-treated larvae $\left(F_{2,9}=26.59, p=\right.$ 0.002; Fig. 5B). The 6 hour-post feeding time represented the accumulation of labeled cholesterol stored in the fat body for the observed period. SCPI-1 and SCPI-2 treatment suppressed cholesterol storage in $M$. sexta larvae within 6 hours of treatment by $37 \%$ and $69 \%$, respectively (Fig. 5C, 6 hour). SCPI-2-treated larvae had significantly less stored $\left[{ }^{3} \mathrm{H}\right]$-cholesterol than the SCPI-1 treated larvae (Fig. 5C, 6 hour) although the amount of labeled cholesterol in the hemolymph in both treatments were similar (Fig. 5B, SCPI-1 and SCPI-2). The result implies that SCPI-2 was more effective than SCPI-1 in blocking the uptake of cholesterol from the hemolymph into the fat body. The results of this study provide the evidence for the first time that SCPIs inhibit cholesterol uptake into the midgut, reduce the efflux of absorbed cholesterol into the hemolymph, and block the uptake of cholesterol in the fat body in vivo in M. sexta larvae.

Vertebrate SCP-2 binds to fatty acid and cholesterol [26]. To investigate whether MsSCP-2 is also involved in fatty acid transport in the midgut, we fed labeled $\left[{ }^{3} \mathrm{H}\right]$ palmatic acid in a label/chase experiment as described above. In the midgut tissue of the control group, there was a significant rapid decrease $(p=0.05)$ in the levels of [3 $\mathrm{H}]$-palmatic acid from 2 to 6 hours post feeding (Fig. $6 \mathrm{~A})$, indicating a very quick clearance of absorbed labeled fatty acid in the midgut. This is consistent with the previous reports that showed rapid uptake and clearance of free fatty acid from the midgut into the hemolymph 
A.

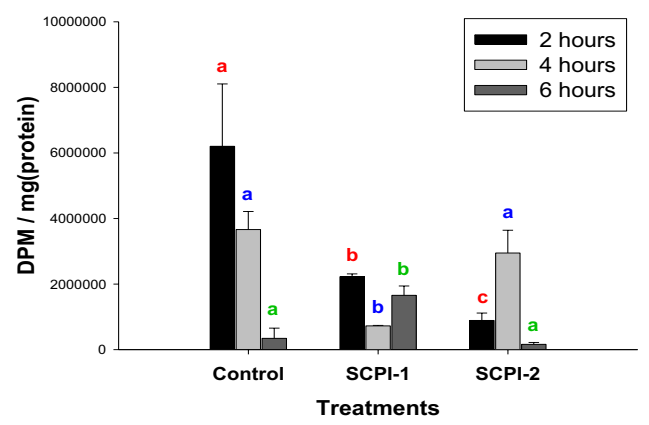

B.

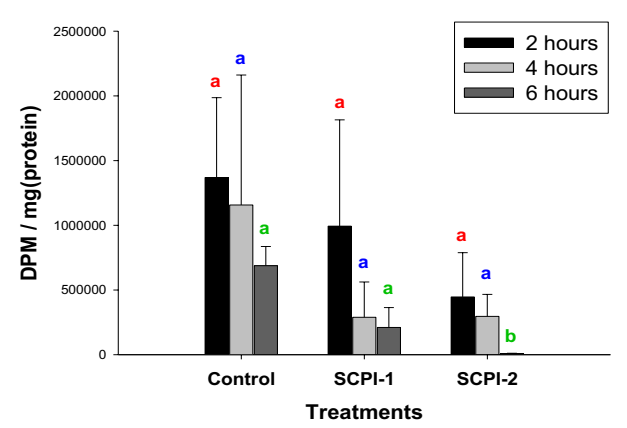

C.

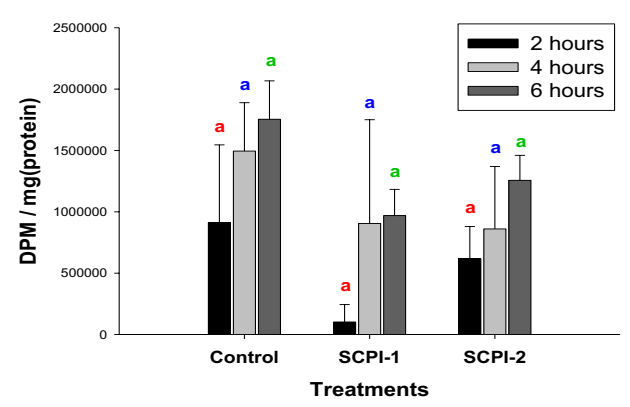

Figure 6 Effects of SCPIs on $[9,10-3 \mathrm{H}]$-palmitic acid uptake in $\boldsymbol{M}$. sexta Day $34^{\text {th }}$ instar larvae. (A) The midgut. (B) The hemolymph. (C) The fat body. Values $=$ mean \pm S.D. $(\mathrm{N}=2)$. Details of the label/chase experiment are provided in the "Materials and Methods". The same letters above the bars in each time point represent that the mean values did not differ from other group of the same time point significantly ( $p$ $>0.05$ ) in paired t-tests.

within 4 hours post feeding [37,39]. In the SCPI-treated larvae, there was a significant reduction of $\left[{ }^{3} \mathrm{H}\right]$-palmatic acid levels $\left(F_{2,9}=15.15, p=0.0013\right)$ in the midgut tissue except at the 4 hour time point in the SCPI-2 treated group (Fig. 6A), suggesting that there was a generalized suppression in the uptake of free fatty acid from the midgut lumen into the midgut tissue in SCPI-treated larvae. However, there were no significant differences between the controls and SCPI-treated larvae in the quantity of $\left[{ }^{3} \mathrm{H}\right]$-palmatic acid in the hemolymph (Fig.
6B) or in the fat body (Fig. 6C), implying that the clearance of absorbed fatty acid from the midgut and the storage of absorbed fatty acid in the fat body were not affected by SCPI-treatment.

\section{Discussion}

There are multiple steps in the cellular uptake of lipids. This process may be important for insects since receptor or lipoprotein mediated endocytosis and/or exocytosis is not involved in cellular lipid transfer [13]. Lipids can easily diffuse into the outer layer of the cytoplasm membrane where they flip-flop across the membrane bilayer. Cytosolic lipid carriers such as cytosolic fatty acid binding protein and SCP-2 desorbs the free lipids from the cytoplasm membrane and deliver them to the storage site or funnel them into a metabolic pathway $[40,41]$. The mechanisms underlying MsSCP-2-mediated cellular cholesterol uptake are unclear. AeSCP-2 is not a membrane bound protein [31], and MsSCP-2-mediated lipid absorption is unlike membrane transporters, such as NiemannPick C1-like 1 (NPC1-L1) [42]. MsSCP-2 may enhance the desorption of membrane-bound ligand through the collision with membrane-bound cholesterol [9], which, in turn, may lead to a MsSCP-2-mediated cholesterol diffusion into the cytosol. The SCP-2/membrane collision model is the proposed mode for fatty acid transport by the SCP-2 of Yarrowia lipolytica [43].

In an earlier study, sterol carrier protein-2 inhibitors (SCPIs) were identified via high throughput screening using recombinant AeSCP-2 [34]. AeSCP-2 is not a product of the AeSCP-x gene [18]. However, both AeSCP-x and AeSCP-2 belong to the SCP-2 gene family [28]. The SCPIs inhibit ligand binding in both AeSCP-2 and the SCP-2 domain protein of AeSCP-x, although the $\mathrm{EC}_{50} \mathrm{~s}$ of the same SCPI are higher for the SCP-2 domain protein of AeSCP-x than for AeSCP-2 [34]. SCPIs are lethal to both mosquito and Manduca sexta larvae [34]. It was speculated that the Manduca sexta has a protein homologous to that of mosquito AeSCP-2, which was inhibited by SCPIs to cause the biological effects in Manduca larvae [34]. To further investigate the possible existence of Manduca sexta SCP-2 (MsSCP-2), we identified MsSCP$\mathrm{x} / \mathrm{SCP}-2$ via reverse-transcriptase PCR based cloning strategy using degenerate primers designed on the basis of a consensus CDNA sequence within insect SCP-x/SCP2 genes (Fig. 1). In vertebrates, the SCP-x/SCP-2 gene codes two proteins that share a common $13 \mathrm{kDa}$ SCP-2 domain: $58 \mathrm{kDa} \mathrm{SCP}-\mathrm{x}$ and $15 \mathrm{kDa}$ pro-SCP-2, which is post-translationally cleaved to $13 \mathrm{kDa} \mathrm{SCP}-2$ [26]. MsSCP-X has the same domain architecture as vertebrate SCP-x. The full-length of the MsSCP-Z/SCP-2 cDNA encodes a protein of 536 amino acids (GQ869536). The amino acid sequence similarities between MsSCP-2 and 
the SCP-2 domain of SCP-x in other insect species were high $(\geq 60 \%$, Table 1$)$.

Using two pairs of primers that detect the $\mathrm{N}$-terminal 2/3-oxoacyl-CoA thiolase domain and the C-terminal SCP-2 domain, it was discovered that the transcripts for MsSCP-x and MsSCP-2 were differentially regulated based on the abundance of each in the same samples (Fig. $2 \mathrm{~A})$. The differential production of the transcripts was most evident in the midgut and fat body, at which time the midgut had predominantly MsSCP-2 mRNA, whereas the fat body had a much higher level of MsSCP-x transcript (Fig. 2A, lane A). In the cotton leafworm (S. littoralis), two transcripts from a single copy of the SCP-x/ SCP-2 gene were detected [19]. However, in the silkworm (B. mori), alternative splicing seemed to generate two transcripts from a single copy of the SCP-x/SCP-2 gene [27]. The first $46 \mathrm{bps}$ of the 5 'end UTR sequence of MsSCP-x is divergent from the MsSCP-x 5' UTR or the sequence corresponding to the SCP-2 domain (Fig. 1, shaded sequence in 5' UTR of the MsSCP-2 cDNA sequence), whereas the identical sequence in the 5' UTR of MsSCP-2 to the SCP-2 domain of the MsSCP-x transcript started at the same position as the splicing site in the B. mori SCP-x/SCP-2 gene (Fig. 1, bold letter "g" in MsSCP-2 5' UTR; [27]). Whether the MsSCP-x/SCP-2 gene may produce two transcripts via alternative splicing needs further investigation.

The spatial expression protein files of MsSCP-x are different from those described in S. littoralis and B. mori, in which the SCP-x transcript level is higher in the midgut and Malpighian tubules. In contrast, the MsSCP-x mRNA levels were much lower in the midgut than in other tissues in general (Fig. 2A). The spatial transcription profiles of MsSCP-x and MsSCP-2 are similar to the mRNA levels of the vertebrate SCP-2 gene. The vertebrate SCP-x is detected essentially in all tissues, whereas SCP-2 was in highest abundance in the liver and intestine [26]. The MsSCP-2 transcription levels were higher in the midgut and fat body during the feeding stage (Fig. 2A, lanes A to D); the metabolic function of the fat body is similar to that of the vertebrate liver and adipose tissue. However, the insect SCP-x protein appears to be processed post-translationally to produce two proteins: the 2/3-oxoacyl-CoA thiolase and the SCP-2 [18,19], which would render higher protein levels of SCP-2 in tissues transcribing $\mathrm{SCP}-\mathrm{x}$ at higher levels.

The anti-SCP-2 domain of AeSCP-x antibodies recognized the purified recombinant MsSCP-2 (Fig. 2B, lane 8) and detected a similar molecular weight immune-reactive protein in the midgut, hindgut, and fat body (Fig. 2B). This result coincides with the fact that the insect midgut is the main site for cholesterol and fatty acid uptake [38]. This also showed the expression pattern of MsSCP- $\mathrm{x} /$ SCP-2 is similar to other mosquito SCP-x and SCP-2 genes. In Aedes aegypti, AeSCP-2 and AeSCP-x were strongly expressed in the foregut and mostly in the midgut during the larval feeding stages [18,20]. In Aedes aegypti, Spodoptera littoralis and Bombyx mori, SCP-xs had high levels of transcription in the midgut during the last larval feeding stages $[18,19,27]$, however, the SCP-2 domain protein is the prominent product due to posttranslational processing of the $\mathrm{SCP}-\mathrm{x}$ protein in the midgut $[18,19]$. Therefore, regardless of which transcript of the SCP-x/SCP-2 gene is predominant in the midgut, high levels of SCP-2 domain protein may be the end result.

There was $56 \%$ less $(p=0.03)$ stored $\left[{ }^{3} \mathrm{H}\right]$-cholesterol 6 hours post feeding in the fat body in SCPI-2-treated larvae than for the SCPI-1-treatment (Fig. 6C, SCPI-1 and SCPI-2). In Manduca sexta GV1 cells, SCPI-1 and SCPI2 at $10 \mu \mathrm{M}$ concentrations suppressed cholesterol uptake by $15 \%$ and $22 \%$, respectively [34]. The relatively higher binding affinities of SCPI- 2 than that of SCPI- 1 to insect SCP-2 [34] (Fig. 4) may result in the differences in biological effects between SCPI-1 and SCPI-2 treatments in which SCPI-2 constantly showed higher efficacy in inhibiting cholesterol trafficking in vivo (Fig. 6A and 6C). The results were consistent with the earlier observation that SCPI-2 is more lethal than SCPI-1 to Manduca larvae [34]. Both SCPI-1 and SCPI-2 effectively inhibited cholesterol uptake (Fig. 6). There was little labeled cholesterol detected in the feces 2 hours post feeding and a significant increase in $\left[{ }^{3} \mathrm{H}\right]$-cholesterol in the feces over the observed time period in the control group (Additional file 1), although the excretion of labeled fatty acid during the same period was constant (Additional file 2). The underlying mechanism for the slower excretion of cholesterol than that of fatty acid in feces is unknown. However, $\left[{ }^{3} \mathrm{H}\right]$-cholesterol levels in the feces within the 6 hour period were $265.84 \%\left(F_{1,6}=31.30, p=0.0014\right)$ and $369.02 \%\left(F_{1,6}=11.35, p=0.015\right)$ higher in SCPI-1- and SCPI-2 treated larvae, respectively, than in the controls (Additional file 1). The results indicate that unabsorbed dietary cholesterol was excreted via feces.

Studies using the vertebrate model suggest that SCP-2 mediates cholesterol trafficking and metabolism and is involved in fatty acid uptake $[26,44]$. However, it is unclear whether insect SCP-2 has similar functions in cholesterol and fatty acid trafficking and metabolism. We investigated the function of MsSCP-2 in vivo using sterol carrier protein-2 inhibitors (SCPIs) to examine the biological effect of MsSCP-2 impairment on cholesterol and fatty acid uptake in M. sexta larvae. Inhibition of MsSCP2's function by SCPIs resulted in arrested growth and development in surviving larvae, indicated by lower weight gain over time and delayed pupation (data not shown). When Manduca larvae were fed $\mathrm{LC}_{50}$ concentra- 
tions of SCPI-1 and SCPI-2 for a short time (within 6 hours, see "Methods"), there was a significant reduction in the uptake of labeled cholesterol in the midgut and fat body in SCPI-treated larvae compared to the controls (Fig. 5A and 5C). Similar results were obtained when NBD-cholesterol, a fluorescent cholesterol analog, was used as the tracer for cholesterol uptake in vivo (Additional file 2). However, the effect of SCPI-treatment on palmatic acid was limited to the suppression of uptake into the midgut (Fig. 6A and 6C). In insects, the mechanism for the uptake of lipids from the diet into the midgut is unclear. It is hypothesized that lipids (free fatty acid and cholesterol) may be transported into the midgut epithelium via specific membrane transporters, and then trafficked intracellularly by carrier proteins toward the basal side of the midgut for uploading onto the Lp [7]. The efficacy of a SCPI in suppressing cholesterol absorption (Fig. 5A and 5C) seemed to correlate with its efficiency in inhibiting ligand-binding in SCP-2 (Fig. 4) [34], suggesting that intracellular transport plays a critical role in cellular uptake of cholesterol. The fact that inhibition of MsSCP-2's function via SCPIs did not completely abolish cholesterol uptake points to the possibility that there may be more than one class of intracellular carrier proteins for cholesterol in insects. Another candidate as an intracellular cholesterol carrier is the steroid acute regulator protein (StAR)-related lipid transfer protein [21,22].

The mode of larvicidal activity of SCPIs against some insect species, including Aedes aegypti, Anopheles gambiae, Culex pipiens and M. sexta is unclear [34,45]. The relatively high binding affinities of SCPI-1 and SCPI- 2 to insect SCP-2s indicate that SCPIs may inhibit the biological functions of SCP-2 by competing with cholesterol for binding to SCP-2 [34]. SCPI-1 and SCPI-2 suppressed $\left[{ }^{3} \mathrm{H}\right]$-cholesterol efflux from the midgut to the hemolymph in $M$. sexta larvae within 6 hours of treatment (Fig. $5 \mathrm{~B})$, resulting in the reduction of stored $\left[{ }^{3} \mathrm{H}\right]$-cholesterol by $37 \%$ and $69 \%$, respectively (Fig. $5 \mathrm{C}$ ). Although, SCPI-1 and SCPI-2 also suppressed $\left[{ }^{3} \mathrm{H}\right]$-palmatic acid uptake in the midgut (Fig. 6A), there was no evidence that SCPItreatment impaired the efflux of absorbed $\left[{ }^{3} \mathrm{H}\right]$-palmatic acid from the midgut into the hemolymph (Fig. 6B). One plausible explanation for the lack of SCPI's effect on the efflux of fatty acid into the hemolymph and ultimately storage in the fat body may be the redundant function of fatty acid binding proteins in the midgut and fat body [46]. The results of this study provide evidence that SCPIs inhibit cholesterol uptake/storage in insects in vivo. The effect of SCPI-treatment on fatty acid uptake in larvae was limited to the midgut (Fig. 6). Since insects can synthesize fatty acid de novo from acetate $[47,48]$, one possible mode of action of SCPIs' larvicidal activities is reduction in cholesterol uptake over time resulting in a deficiency in cholesterol that might lead to a high mortal- ity rate in SCPI-treated Manduca larvae [34]. The likely mechanism of SCPIs in inhibiting cholesterol absorption is the decrease in clearance of absorbed cholesterol from the midgut tissue (Fig. 4B), suggesting that MsSCP-2 may be involved in the cellular trafficking of cholesterol in the midgut.

\section{Conclusions}

In this study we tested the hypothesis that MsSCP-2 may be involved in cholesterol uptake and intracellular transportation. Our results show that Manduca sexta sterol carrier protein- $\mathrm{x}$ and sterol carrier protein-2 (MsSCP-x/ SCP-2) have a high degree of homology in the SCP-2 domain to other insects' SCP-2 and recombinant MsSCP2 bound to NBD-cholesterol with high binding affinity. Transcripts of MsSCP-2 were highly expressed in the larval midgut and fat body. The result suggests that MsSCP2 may be involved in cholesterol uptake in the midgut, the main site for cholesterol absorption, and intracellular transportation in the fat body, the main site for cholesterol storage. MsSCP-2 may function as a lipid carrier protein in vivo.

We have also shown that sterol carrier protein inhibitors (SCPIs) effectively reduced cholesterol uptake and cholesterol accumulation in the midgut and in fat body.

Due to the total dependence of insects on exogenous cholesterol, targeting insect SCP-2 may be a viable approach for the development of new insecticides.

\section{Methods}

\section{Chemicals}

Chemicals and reagents were purchased from Sigma (Sigma, St. Louis, MO, USA), Fisher Scientific (Pittsburgh, PA, USA) and ICN (Costa Mesa, CA, USA) if their origins were not mentioned in the text. $\left[1,2-{ }^{3} \mathrm{H}(\mathrm{N})\right]$-cholesterol $(40 \mathrm{Ci} / \mathrm{mMol})$ and $\left[9,10-{ }^{3} \mathrm{H}\right]$-palmitic acid $(60 \mathrm{Ci} /$ $\mathrm{mMol}$ ) were purchased from American Radiolabeled Chemicals, Inc. (St. Louis, MO, USA). AeSCP-2 inhibitors, SCPI-1 (N-4-\{[4-(3,4-dichlorophenyl)-1,3-thiazol-2yl]amino\}phenyl)aetamide hydrobromide) and SCPI-2 (8chloro-2-(3-methoxyphenyl)-4,4-dimethyl-4,5-dihydroisothiazol[5,4-c]quinoline-1(2H)-thione), were purchased from ChemBridge Corporation (San Diego, CA, USA) with at least $90 \%$ purity. NBD cholesterol was purchased from Molecular probes (Eugene, OR, USA).

\section{The tobacco hornworm, Manduca sexta}

Manduca sexta eggs were a gift from Dr. Walter G. Goodman, University of Wisconsin-Madison. Larvae were fed a commercial gypsy moth wheat germ diet (ICN Biomedicals, Irvine, CA), and reared at $25^{\circ} \mathrm{C}$ and $60 \%$ relative humidity, under a 16:8 (Light:Dark) cycle. Fresh food was provided every other day. Fourth instars were selected by observing head capsule slippage at the time of 
the molt from the $3^{\text {rd }}$ instar and were gated by weight (> $0.35 \mathrm{~g}$, but $<0.54$ g at $24 \mathrm{~h} 4^{\text {th }}$ instar and $>0.65 \mathrm{~g}$, but $<0.85$ $\mathrm{g}$ at $48 \mathrm{~h} 4^{\text {th }}$ instar) [49]. Only gate II larvae were used for each set of experiments.

\section{RNA extraction and CDNA synthesis of the first strand}

Total RNA was extracted from the Day $34^{\text {th }}$ instar Manduca sexta larvae using TRIzol (Invitrogen, USA) according to the manufacturer's instruction. The midgut was dissected in cold Manduca saline solution [50] under a dissecting microscope and homogenized immediately in $1 \mathrm{ml}$ TRIzol reagent. Five micrograms of each RNA sample were further purified using the TURBO DNA-free Kit (Ambion, Austin, TX, USA). The corresponding first strand cDNAs were reverse transcribed from $0.5 \mu \mathrm{g}$ DNA-free total RNA using Reverse Transcription Kit (Invitrogen, USA). The quantity of the RNA samples was determined by $\mathrm{UV}_{260}$ absorption with a NanoDrop ${ }^{\mathrm{TM}} 1000$ spectrophotometer (NanoDrop products, Wilmington, DE).

\section{Molecular cloning of MsSCP-x/SCP-2 gene}

Two degenerate primers were designed for cloning based on the consensus partial cDNA sequence of the SCP-2 domain from Bombyx mori (BmSCP-2) and Spodoptera littoralis (SISCP-2). MsSCP-CF1: 5'-CAA ATA CAT GAA GAT CCT TGA-3' and MsSCP-CR1: 5'-TCA ATC CTG CCA GCG GCT TG-3' match to the N-terminal and the C-terminal of the SCP-2 domain, respectively (Fig. 1).

The SMART RACE cDNA Amplification Kit (Clontech, Palo Alto, CA) was used for the 5'-RACE and the 3'RACE with cDNAs made from the midgut of Day $34^{\text {th }}$ instars. The PCR products were separated on $1 \%$ agarose gel, purified with a QIAquick Gel Extraction Kit (QIAGEN, Valencia, USA), cloned into pCR-Blunt II-TOPO ${ }^{\circ}$ blunt plasmid (Invitrogen, Carlbad, CA), transformed into the INV $110 \mathrm{E}$. Coli strain (One Shot competent cells) (Invitrogen, Carlsbad, CA) and plated on LB plates under Kanamycin selection. Plasmid minipreps of seven clones containing inserts were made using a QiaSpin column (QIAGEN, Valencia, CA) and sequenced in an automatic sequencer (ABI 377XL) using BigDye labeling (Amersham Pharmacia Biotech AB, Uppsala, Sweden). Another degenerate primer (xNF: 5'-TTC AAC GAC AGA ACC AAC CC-3') designed based on the consensus cDNA sequences of the 2/3-oxoacyl-CoA thiolase domain from Bombyx mori (BmSCP-x) and Spodoptera littoralis (SISCP-x), and gene specific primers (MsSCPCR2: 5'-AAA CGG GAC CTA GAA CTA GAA CGG-3, and MsSCP-CR3: 5'-AGA ACT AGA ACG GGA CCT TC-3') derived from the partial cDNA sequence of MsSCP-2 were used to obtain the coding region of the MsSCP-x/SCP-2 gene (Fig. 1). Additional gene specific primer (MsSCP-CR4: 5'-TGG CAA GGT GCA CCT
CTG-3', MsSCP-CF2: 5'-TAC GGG TTC AAG GTC AGG AAT GGA-3', and MsSCP-CF3: 5'-AAA CCC GAC GTC ACT TTC AC-3') derived from the coding region was synthesized and used for the $5^{\prime}$-and 3 '-RACE to obtain the 5'-and 3'-end of the CDNA. All PCR reactions for MsSCP-2 gene amplification were performed as follows: initial denaturing at $95^{\circ} \mathrm{C}$ for 3 minutes, followed by 30 cycles of denaturing at $94^{\circ} \mathrm{C}$ for 30 seconds, annealing at $61^{\circ} \mathrm{C}$ for 30 seconds, and extension at $72^{\circ} \mathrm{C}$ for $30 \mathrm{sec}-$ onds with a final extension of $72^{\circ} \mathrm{C}$ for 2 minutes. The PCR products were cloned, transformed and sequenced as described above.

\section{Purification of recombinant MsSCP-2}

To produce recombinant MsSCP-2 (rMsSCP-2), PCR products of the entire coding region of the MsSCP-2 gene were cloned into the pGEX-4T-2 GST tag vector (Amersham Pharmacia). PCR primers were 5'-ggctggatcccCCCGAGGAGTTCAAAG TG-3' (capital letters are coding sequence; bold letter is the first codon of the MsSCP-2 domain; a BamHI site was incorporated for cloning) and 5'-ccggtgaattcgaCTA CAGTTTGGAGCGG-3' (capital letters are the antisense of the coding sequence; bold letter is the antisense of the stop codon; the EcoRI site was incorporated for cloning). The expression vector was transferred into the INV $110 \mathrm{E}$. coli strain (One Shot competent cells) (Invitrogen, Carlsbad, CA) under $100 \mu \mathrm{g} / \mathrm{ml}$ ampicilin selection. Sequence analysis was performed to confirm that the fusion protein was in the frame with the GST. The rMsSCP-2 expression bacteria were incubated in $200 \mathrm{ml}$ Luria-Bertani (LB) medium with $100 \mu \mathrm{g} / \mathrm{ml}$ ampicilin at $37^{\circ} \mathrm{C}$ overnight, 50 $\mathrm{ml}$ overnight bacterial culture was added into $500 \mathrm{ml}$ fresh LB medium with $100 \mu \mathrm{g} / \mathrm{ml}$ ampicilin and grown at $37^{\circ} \mathrm{C}$ for 2 hours $\left(\mathrm{OD}_{600}=0.8\right)$. Then, expression of rMsSCP-2 was induced by the addition of isopropyl-betaD-thiogalactoside (IPTG) to a final concentration of 0.2 $\mathrm{mM}$ and the culture was incubated at $18^{\circ} \mathrm{C}$ for about 6 hours.

Cells from the 2.5 L LB medium were harvested by centrifuge at $4000 \times \mathrm{g}$ for 15 minutes, and then the cellular pellets were resuspended in $30 \mathrm{ml}$ of PBS $(140 \mathrm{mM} \mathrm{NaCl}$, $10 \mathrm{mM} \mathrm{Na}_{2} \mathrm{HPO}_{4}, 1.8 \mathrm{mM} \mathrm{KH} \mathrm{PO}_{4}, 2.7 \mathrm{mM} \mathrm{KCl}, \mathrm{pH}$ 7.4) with $5 \mathrm{mM}$ DTT and $2 \mathrm{mM}$ EDTA. Cells were lysed using a sonic dismembrator (model 300, Fisher, USA). The cell lysate was centrifuged at $20000 \times \mathrm{g}$ for 1 hour to remove cellular debris. The GST/rMsSCP-2 fusion protein was purified on a GST affinity column $(10 \mathrm{ml}$ bed volume; Amersham Pharmacia) and the GST tag was cleaved by digesting with 500 units of Thrombin (Amersham Pharmacia) in the column at $4^{\circ} \mathrm{C}$ overnight. Thrombin was removed from the eluted $\mathrm{rMsSCP}-2$ by passing it through a benzamidine column (Amersham Pharmacia). Purified rMsSCP-2 was concentrated in a Centricon YM-10 
device (Amicon) to $1 \mathrm{mg} / \mathrm{ml}$ in a phosphate saline buffer (PBS), $\mathrm{pH} 7.4$, stored in $\mathrm{PBS}$ at $-80^{\circ} \mathrm{C}$. Concentration of the protein was determined using UV $280 \mathrm{~nm}$ absorbed coefficiency.

\section{Tissue and stage expression profiles of MsSCP-x/SCP-2}

To investigate the transcription profiles of MsSCP- $\mathrm{x} /$ SCP-2 in different tissues at different developmental stages, total RNAs from the hemolymph (hemocytes), midgut, hindgut, fat body, muscle and epidermis were extracted from Manduca sexta at different stages (Day 1 $4^{\text {th }}$ instar, Day $34^{\text {th }}$ instar, Day $15^{\text {th }}$ instar, Day $45^{\text {th }}$ instar, wandering stage, and pupal stage) and homogenized in 1 ml TRIzol reagent (Invitrogen, USA). Genomic DNA contamination in the $5 \mu \mathrm{g}$ total RNA samples was treated twice with the TURBO DNA-free ${ }^{\mathrm{m}}$ kit (Ambion, USA) and the samples were tested via PCR with MsSCP-2 gene specific primers to verify the RNA samples were free of genomic DNA. Reverse transcription was performed using $0.5 \mu \mathrm{g}$ DNA-free total RNA and a Reverse Transcription Kit (Invitrogen, USA). Two microliters of the first strand cDNA (equivalent to 50 ng total RNA) was used as a template for MsSCP-x, MsSCP-2 and rpS3 amplification. MsSCP-2 gene-specific forward (MsSCPCF2) and reverse primers (MsSCP-CR2) were used for the PCR reaction (the expected PCR product was 210 bps; Fig. 1). To detect the MsSCP-x transcript, primers corresponding to the partial sequence of the 2/3-oxoacyl$\mathrm{CoA}$ thiolase domain (forward primer: xNF; reverse primer: MsSCP-CR4) were used for the PCR reaction (the expected PCR product was 151 bps; Fig. 1). Ribosomal protein $\mathrm{S} 3$ (rpS3) cDNA fragment was amplified with rpS3-F (5'-TTA ATT CCG AGC ACT CCT TG-3') and rpS3-R (5'-GGA GCT GTA CGC TGA GAA AG-3') primers [51] as an internal control. PCR reactions for MsSCP-2 and MsSCP-x gene amplification were performed as follows: initial denaturing at $95^{\circ} \mathrm{C}$ for $3 \mathrm{~min}$ utes, followed by 30 cycles of denaturing at $94^{\circ} \mathrm{C}$ for 30 seconds, annealing at $61^{\circ} \mathrm{C}$ for 30 seconds, and extension at $72^{\circ} \mathrm{C}$ for 30 seconds with a final extension of $72^{\circ} \mathrm{C}$ for 2 minutes. PCR control reaction for ribosomal protein S3 (rpS3) was performed as follows: initial denaturing at $95^{\circ} \mathrm{C}$ for 3 minutes, followed by 30 cycles of denaturing at $94^{\circ} \mathrm{C}$ for 30 seconds, annealing at $50^{\circ} \mathrm{C}$ for 30 seconds, and extension at $72^{\circ} \mathrm{C}$ for 60 seconds with a final extension of $72^{\circ} \mathrm{C}$ for 2 minutes. The PCR products were separated on $1 \%$ agarose gel.

\section{Western blotting analysis of MsSCP-2 expression}

Day $15^{\text {th }}$ instars were chilled in ice water for 10 minutes; tissues were dissected out in cold Manduca saline solution [50] under a dissecting microscope. Isolated tissues were homogenized in Manduca saline solution containing a $0.5 \mathrm{mM}$ benzamidine hydrochloride, $2 \mathrm{mM}$ EDTA,
$0.5 \mathrm{mM}$ phenylmethylsulfonyl fluoride, $0.1 \mathrm{mM}$ glutathione, and $0.1 \mathrm{mM}$ protease inhibitor cocktail (Sigma). Concentrations of soluble proteins in each tissue sample were determined using a BCA Protein Assay Kit (Pierce, Rockford, IL, USA).

Proteins $(20 \mu \mathrm{g})$ from each sample were resolved on a 4$20 \%$ pre-casted gradient SDS PAGE gel (ISC Bioexpress, Kaysville, UT, USA) and transferred onto a Hybond-C extra membrane (Amersham BioScience, Piscataway, NJ, USA) at 18 volts overnight in Tris-glycine transfer buffer $(0.303 \%$ Tris base, $1.44 \%$ glycine, $20 \%$ methanol) as described [52]. The membrane was incubated for 1 hour in a blocking solution (5\% BSA, 5\% normal goat serum, $0.5 \%$ Tween-20 in phosphate saline buffer (PBST), pH7.4) at room temperature, and affinity purified polyclonal anti-SCP-2 domain of AeSCP-x [18] (1:3000 dilution) was added into the blocking solution and incubated another 1 hour. After 4 washes of 15 minutes each with PBST, the blot was incubated with AP (alkaline phophatase)-conjugated goat anti-rabbit IgG (Jackson ImmunoResearch Laboratories, INC., West Grove, PA, USA) at a 1:2000 dilution in PBST for 1 hour at room temperature. After 4 washes of 15 minutes each with PBST, alkaline phosphate substrate solution $(100 \mathrm{mM}$ Tris- $\mathrm{Cl} \mathrm{pH} 9.5,100 \mathrm{mM}$ $\mathrm{NaCl}, 5 \mathrm{mM} \mathrm{MgCl}$, with $33 \mu \mathrm{l}$ of NBT and $17 \mu \mathrm{l}$ of BCIP in $5 \mathrm{ml}$ of solution) was used to visualize the secondary bound antibodies, which were developed within $30 \mathrm{~min}$ utes at room temperature.

\section{Ligand and SCPIs binding in MsSCP-2}

MsSCP-2 binding affinity for NBD-cholesterol, an analog of cholesterol, was determined using NBD-cholesterol binding assays. A $1 \mathrm{ml}$ sample of $10 \mu \mathrm{M}$ recombinant MsSCP-2 was diluted with $10 \mathrm{mM} \mathrm{KHPO}_{4}$ buffer (pH 7.4) to various concentrations $(1 \mathrm{nM} \sim 10 \mu \mathrm{M})$. Twenty-five microliters of each concentration of MsSCP-2 solution and the control (without MsSCP-2) were thoroughly mixed with $25 \mu \mathrm{l}$ of NBD-cholesterol solution $(1 \mu \mathrm{M}$ in $\mathrm{KHPO}_{4}$ buffer, $\mathrm{pH}$ 7.4) and allowed to equilibrate for 3 minutes to permit stable measurement of the fluorescence signal. NBD-cholesterol fluorescence was excited at $470 \mathrm{~nm}$, and emission was recorded at $530 \mathrm{~nm}$ using a fluorescence microplate reader (Model: GeminiXPS, Molecular Devices). Data were fit using a simple, single binding site, non-linear regression model in GraphPad PRISM ${ }^{\circ}$ software version 4.0 (GraphPad Software Inc., San Diego, CA) using the equation:

$$
\mathrm{Y}=\frac{\operatorname{Bmax} \times X}{K_{\mathrm{d}}+\mathrm{X}}
$$

Where, $\mathrm{K} d$ is the binding affinity, $\mathrm{X}$ is the NBD-cholesterol concentration $(\mu \mathrm{M}), \mathrm{Y}$ is the total binding (fluores- 
cent intensity unit), and Bmax is the maximum specific binding to be fit. AeSCP-2 and GST were used as a positive control and a negative control, respectively. NBDcholesterol binding assays for the controls were performed the same as described above for recombinant MsSCP-2.

The inhibitory effect of SCPI on cholesterol binding to MsSCP-2 was measured using NBD-cholesterol competition assays. In a $50 \mu \mathrm{l}$ reaction solution in each well of a 96-well plate purified recombinant MsSCP-2 $(5 \mu \mathrm{M})$ was incubated with NBD-cholesterol $(1.25 \mu \mathrm{M})$ in the presence of increased concentrations of a SCPI (0-12.5 $\mu \mathrm{M})$ in $10 \mathrm{mM} \mathrm{KHPO}_{4}$ buffer $(\mathrm{pH} \mathrm{7.4})$ for $5 \mathrm{~min}$. The fluorescence intensity (excitation/emission $=470 / 530$ ) of NBDcholesterol was measured. The background control was NBD-cholesterol alone in $10 \mathrm{mM} \mathrm{KHPO}_{4}$ buffer (pH 7.4). A separate set of tests was performed using NBD-cholesterol with increasing concentrations of a SCPI to assess whether a SCPI interfered with NBD-cholesterol fluorescence. If a SCPI interfered with NBD-cholesterol fluorescence, the background control was NBD-cholesterol along with the SCPI. The net change in NBD-cholesterol fluorescence intensity was calculated by subtracting the fluorescence of the background control from the NBDcholesterol-MsSCP-2 complex in the absence or presence of an inhibitor. The data were plotted with the relative NBD-cholesterol fluorescent intensity (bound NBD-cholesterol) as the $y$-axis and the molarities of the inhibitor as the $\mathrm{x}$-axis. Bacterial GST protein and Aedes aegypti $\mathrm{SCP}-2$ protein (AeSCP-2) were used as a negative control and a positive control for the assays, respectively.

\section{Effects of SCPIs on lipids uptake}

To examine the effect of SCPIs on lipid absorption/trafficking (label/chase), gate II third day $4^{\text {th }}$ instar $M$. sexta were fasted for $2 \mathrm{hr}$, and then were fed a small piece of diet $(0.1 \mathrm{~g})$ containing SCPIs at $\mathrm{LD}_{50}$ dosage [34] in $2 \mu \mathrm{l}$ of ethanol and $\left[{ }^{3} \mathrm{H}\right]$-cholesterol $(0.033 \mu \mathrm{Ci} / \mathrm{ml}$ ethanol $)$ or 2 $\mathrm{ul}$ of $\left[{ }^{3} \mathrm{H}\right]$-palmatic acid. For the control group, a small piece of diet $(0.1 \mathrm{~g})$ containing only $2 \mu \mathrm{l}$ of ethanol and $\left[{ }^{3} \mathrm{H}\right]$-cholesterol $(0.033 \mu \mathrm{Ci} / \mathrm{ml}$ ethanol $)$ or $\left[{ }^{3} \mathrm{H}\right]$-palmatic acid was provided to the larvae. Larvae that consumed the diet completely within 30 minutes were selected for the following experiments in three groups (control, SCPI1 and SCPI-2) of 6 insects ( 2 insects/time). From the control and treated groups, hemolymph, the midgut tissue, the fat body, and feces from each individual larva were collected at 2, 4 and $6 \mathrm{hr}$ after feeding. The larvae were anesthetized on ice for 5 minutes, the hemolymph was collected via a small cut at the base of the horn and the hemolymph was bled into a clear test tube by gently pressing the larvae body. The entire midgut was dissected out in cold Manduca saline solution [50] containing 0.5
$\mathrm{mM}$ benzamidine hydrochloride, $2 \mathrm{mM}$ EDTA, $0.5 \mathrm{mM}$ phenylmethylsulfonyl fluoride, $0.1 \mathrm{mM}$ glutathione, and $0.1 \mathrm{mM}$ protease inhibitors cocktail (Sigma). The dissected midgut was washed in cold PBS to clean off the food content. The fat body was carefully dissected and washed extensively with cold PBS buffer. Collected tissue samples were stored at $-80^{\circ} \mathrm{C}$. Frozen samples were thawed and homogenized with micropestle in $1 \mathrm{ml}$ of $\mathrm{n}$ hexane:2-propanol (v:v 3:2). Total lipids including $\left[{ }^{3} \mathrm{H}\right]$ cholesterol or $\left[{ }^{3} \mathrm{H}\right]$-palmatic acid were extracted from the midgut, hemolymph, fat body, and feces, using $1 \mathrm{ml}$ of $\mathrm{n}$ hexane:2-propanol ( $v: v$ 3:2). Extracts were centrifuged at $2500 \mathrm{rpm}$ to pellet the denatured protein and other cellular debris. The organic phase containing [ $\left.{ }^{3} \mathrm{H}\right]$-lipid was decanted and air dried, then the radioactivity was measured in a $5 \mathrm{ml}$ high flash-point LSC-cocktail (PerkinElmer, Waltham, MA) using a liquid scintillation analyzer TriCarb 2500TR (Packard, Meriden, CT, USA). The denatured protein pellet was dried overnight at room temperature to evaporate the residual organic solvent. The dried protein from the extracts was dissolved overnight in $0.2 \mathrm{M} \mathrm{KOH}$ at $65^{\circ} \mathrm{C}$ and the protein concentration was determined using a BCA Protein Assay Kit (Pierce, Rockford, IL). For the tissue samples, radioactivity and protein content were quantified and expressed as $\left[{ }^{3} \mathrm{H}\right]$-lipid (DPM)/mg soluble protein. For the feces sample, the total radioactivity was directly quantified.

\section{Statistics}

Data were analyzed with two-way ANOVA (GLM procedure) to determine if the control group and SCPIs treated groups differed significantly. Student t-test was used in cases where a pair of treatments was compared to determine the significance of the differences [53].

\section{Additional material}

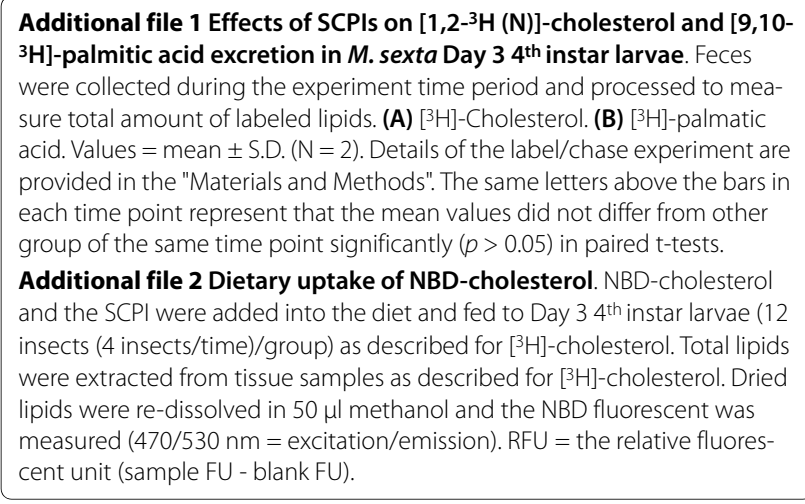

Abbreviations

NBD cholesterol: 22-(N-(7-nitrobenz-2-oxa-1,3-diazol-4-yl)amino)-23,24-bisnor5-cholen-3 $\beta$-ol; SCP-x: sterol carrier protein 2/3-oxyacyl-CoA thiolase; SCP-2: sterol carrier protein-2; SCPI: sterol carrier protein-2 inhibitor; Lp: lipophorin. 


\section{Authors' contributions}

MK and QL designed the study and wrote the manuscript together. MK performed the experiments. Both authors read and approved the final manuscript.

\section{Acknowledgements}

We thank Dr. Walter G. Goodman for the supply of Manduca sexta eggs. We thank Drs. Kenneth F. Raffa, Walter G. Goodman, Robert C Williamson, and Dr. Susan M. Smith for critical comments. This work was supported by the University of Wisconsin-Madison College of Agriculture and Life Sciences' USDACSREES Hatch project WIS04963, by grant W9113M-05-1-0006 from the Deployed War Fighter Protection Research Program (DWFP) administered by the U.S. Armed Forces Pest Management Board (AFPMB), and by the National Institutes of Health Research Grant \#5R01Al067422 to Q.L.

\section{Author Details}

1Division of Pharmaceutical Sciences, School of Pharmacy, University of Wisconsin, 777 Highland Avenue, Madison, WI 53705-2222, USA and 2Department of Entomology, University of Wisconsin, 1630 Linden Drive, Madison, WI 53706, USA

Received: 1 December 2009 Accepted: 9 June 2010 Published: 9 June 2010

\section{References}

1. Zdobnov EM, VonMering C, Letunic I, Torrents D, Suyama M, Copley RR, Christophides GK, Thomasova D, Holt RA, Subramanian GM, Mueller HM Dimopoulos G, Law JH, Wells MA, Birney E, Charlab R, Halpern AL, Kokoza E, Kraft CL, Lai Z, Lewis S, Louis C, Barillas-Mury C, Nusskern D, Rubin GM, Salzberg SL, Sutton GG, Topalis P, Wides R, Wincker P, Yandell M, Collins FH, Ribeiro J, Gelbart WM, Kafatos FC, Bork P: Comparative genome and proteome analysis of Anopheles gambiae and Drosophila melanogaster. Science 2002, 298:149-159.

2. Hobson RP: On a fat-soluble growth factor required by blow-fly larvae: Identity of the growth factor with cholesterol. Biochem J 1935, 29(9):2023-2026.

3. Clark AJ, Bloch K: Function of sterols in Dermesters vulpinus. J Biol Chem 1959, 234:2583-2588.

4. Ritter KS, Nes WR: The effects of cholesterol on the development of Heliothis zea. J insect Physio/ 1981, 27(3):175-182.

5. Chino H, Katase H, Downer RG, Takahashi K: Diacylglycerol-carrying lipoprotein of hemolymph of the American cockroach: purification, characterization, and function. J Lipid Res 1981, 22(1):7-15.

6. Prasad SV, Ryan RO, Law JH, Wells MA: Changes in lipoprotein composition during larval-pupal metamorphosis of an insect, Manduca sexta. J Biol Chem 1986, 261(2):558-562.

7. Arrese EL, Canavoso LE, Jouni ZE, Pennington JE, Tsuchida K, Wells MA: Lipid storage and mobilization in insects: current status and future directions. Insect Biochem Mol Biol 2001, 31(1):7-17

8. Renshaw PF, Janoff AS, Miller KW: On the nature of dilute aqueous cholesterol suspension. J Lipid Res 1983, 24:47-51.

9. Leventis R, Sivius JR: Use of cyclodextrins to monitor transbilayer movement and differential lipid affinities of cholesterol. Biophys J 2001, 81(4):2257-2267.

10. Phillips MC, Johnson WJ, Rothblat GH: Mechanisms and consequences of cellular cholesterol exchange and transfer. Biochim Biophys Acta 1987, 906:223-276.

11. Gallegos AM, Atshaves BP, Storey SM, McIntosh AL, Petrescu AD, Schroeder F: Sterol carrier protein-2 expression alters plasma membrane lipid distribution and cholesterol dynamics. Biochemistry 2001, 40:6493-6506.

12. Phillips MC, Gillotte KL, Haynes MP, Johnson WJ, Lund-Katz S, Rothblat GH: Mechanisms of high density lipoprotein-mediated efflux of cholesterol from cell plasma membranes. Atherosclerosis 1998, 137(Suppl):S13-17.

13. Yun HK, Jouni ZE, Wells MA: Characterization of cholesterol transport from migut to fatbody in Manduca sexta larvae. Insect Biochem Mol Biol 2002, 32(9):1151-1158.

14. Prasad SV, Fernando-Warnakulasuriya GJ, Sumida M, Law JH, Wells MA: Lipoprotein biosynthesis in the larvae of the tobacco hornworm, Manduca sexta. J Biol Chem 1986, 261(36):17174-17176.
15. Venkatesh K, Lenz CJ, Bergman DK, Chippendale GM: Synthesis and release of lipophorin in larvae of the southwestern corn borer, Diatraea grandiosella: an in vitro study. Insect Biochem 1987, 17:1173-1180.

16. Bauerfeind R, Komnick H: Lipid-loading and unloading of lipophorin in the midgut epiothelium of dragonfly larvae (Aeshna cyanea): A biochemical and immunocytochemical study. J Insect Physiol 1992, 38(2):147-160.

17. Kitamura T, kobayashi S, Okada M: Regional expression of the transcript encoding sterol carrier protein $\mathrm{x}$-related thiolase and its regulation by homeotic genes in the midgut of Drosophila embryos. Dev Growth Differ 1996, 38(4):373-381.

18. Lan $\mathrm{Q}$, Wessley $\mathrm{V}$ : Expression of a sterol carrier protein-x gene in the yellow fever mosquito, Aedes aegypti. Insect Mol Biol 2004 13(5):519-529.

19. Takeuchi $\mathrm{H}$, Chen JH, Jenkins JR, Bun-Ya M, Turner PC, Rees $H H$ : Characterization of a sterol carrier protein 2/3-oxoacyl-CoA thiolase form the cotton leafworm (Spodoptera littoralis): a lepidopteran mechanism closer to that in mammals than that in dipterans. Biochem J 2004, 382(Part I):93-100.

20. Krebs KC, Lan Q: Isolation and expression of a sterol carrier protein-2 gene form the yellow fever mosquito, Aedes aegypti. Insect Mol Biol 2003, 12(1):51-60

21. Roth GE, Gierl MS, Vollborn L, Meise M, Lintermann R, Korge G: The Drosophila gene Start 1: a putative cholesterol transporter and key regulator of ecdysteroid synthesis. Proc Natl Acad Sci 2004, 101(6):1601-1606.

22. Sieglaff DH, Duncan KA, Brown MR: Expression of genes encoding proteins involved in ecdysteroidogenesis in the female mosquito Aedes aegypti. Insect Biochem Mol Biol 2005, 35(5):471-490. Erratum in Insect Biochem Mol Biol 2005, 35(11):1310

23. Vyazunova I, Wessley V, Kim M, Lan Q: Identification of two sterol carrier protein-like genes in the yellow fever mosquito, Aedes aegypti. Insect Mol Biol 2007, 16(3):305-14.

24. Dyer DH, Vyazunova I, Lorch JM, Forest KT, Lan Q: Characterization of the yellow fever mosquito sterol carrier protein-2 like 3 gene and ligandbound protein structure. Mol Cell Biochem 2009, 326(1-2):67-77.

25. Ohba T, holt JA, Billheimer JT, Strauss JF: Human sterol carrier protein $\mathrm{x} /$ sterol carrier protein-2 gene has two promoters. Biochemistry 1995, 34(33):10660-10668.

26. Gallegos AM, Atshaves BP, Storey SM, starodub O, Petrescu AD, Huang H McIntosh AL, Martin GG, Chao H, Kier AB, Schroeder F: Gene structure, intracellular localization, and functional roles of sterol carrier protein2. Prog Lipid Res 2001, 40:498-563.

27. Gong J, Hou Y, Zha X, Lu C, Zhu Y, Xia Q: Molecular cloning and characterization of Bombyx mori sterol carrier protein $\mathrm{x} / \mathrm{sterol}$ carrier protein 2 (SCPx/SCP2) gene. DNA sequence 2006, 17(5):326-333.

28. Vyazunova I, Lan Q: Insect sterol carrier protein-2 gene family: structures and function. In Recent Advances in Insect Physiology, Toxicology and Molecular Biology Edited by: Liu N. Kerala. India: Research Signpost; 2007:173-198.

29. Ferdinandusse $\mathrm{S}$, Kostopoulos P, Denis $\mathrm{S}$, Rusch $\mathrm{H}$, Overmars H, Dilmann U, Reith W, Haas D, Wanders RJA, Duran M, Marziniak M: Mutations in the gene encoding peroxisomal sterol carrier protein $\mathrm{x}(\mathrm{SCPx})$ cause leukencephalopathy with dystonia and motor neuropathy. Am J Hum Genet 2006, 78:1046-1052.

30. Atshaves BP, McIntosh AL, Landrock D, Payne HR, Mackie JT, Maeda N, Ball J, Schroeder R, Kier AB: Effect of SCP-x gene ablation on branched-chain fatty acid metabolism. Am J Physiol Gastrointest Liver Physiol 2007, 292:939-951.

31. Lan Q, Massey RJ: Subcellular localization of the mosquito sterol carrier protein-2 and sterol carrier protein-x. J Lipid Res 2004, 45:1468-1474.

32. Dyer DH, Lovell S, Thoden JB, Holden HM, Rayment I, Lan Q: The structural determination of an insect sterol carrier protein-2 with a ligand-bound C16 fatty acid at 1.35 Å resolution. J Biol Chem 2003, 278:39085-39091.

33. Blitzer EJ, Vyazunova I, Lan Q: Functional analysis of AeSCP-2 using gene expression knockdown in the yellow fever mosquito, Aedes aetypti. Insect Mol Biol 2005, 14(3):301-307.

34. Kim M, Wessley V, Lan Q: Identification of mosquito sterol carrier protein-2 inhibitors. J Lipid Res 2005, 46(4):650-657. 
35. Svoboda JA, Weirich GF: Sterol metabolism in the tobacco hornworm, Manduca sexta - a review. Lipids 1995, 30:263-267.

36. Greewood DR, Dinan LN, Rees HH: Mechanism of hydroxylation at C-2 during the biosynthesis of ecdysone in ovaries of the locust, Schitocerca gregaria. Biochem J 1984, 217:783-789.

37. Canavoso LE, Wells MA: Metabolic pathways for diacylglycerol biosynthesis and release in the midgut of larval Manduca sexta. Insect Biochem Mol Biol 2000, 30(12):1173-1180.

38. Jouni ZE, Zamora J, Wells MA: Absorption and tissue distribution of cholesterol in Manduca sexta. Arch Insect Biochem Physiol 2002, 49(3):167-175.

39. Tsuchida K, Wells ME: Digestion, absorption, transport and storage of fat during the last larval stadium of Manduca sexta. Changes in the role of lipophorin in the delivery of dietary lipid to the fat body. Insect Biochem 1988, 18:263-268

40. Stremmel W, Pohl L, Ring A, Herrmann T: A new concept of cellular uptake and intracellular trafficking of long-chain fatty acids. Lipids 2001, 36(9):981-989.

41. Maxfield FR, Menon AK: Intracellular sterol transport and distribution. Curr Opin Cell Biol 2006, 18(4):379-385.

42. Wang J, Chu BB, Ge L, Li BL, Yan Y, Song BL: Membrane topology of human NPC1L1, a key protein in enterohepatic cholesterol absorption. J Lipid Res 2009, 50(8):1653-1662.

43. Falomir Lockhart LJ, Burgardt NI, Ferreyra RG, Ceolin M, Ermácora MR, Córsico B: Fatty acid transfer from Yarrowia lipolytica sterol carrier protein 2 to phospholipid membranes. Biophys J 2009, 97(1):248-256.

44. Murphy EJ: Sterol carrier protein-2: not just for cholesterol anymore. Mol Cell Biochem 2002, 239(1-2):87-93.

45. Larson RT, Wessley V, Jiang Z, Lan Q: Larvicidal activity of sterol carrier protein-2 inhibitors in four species of mosquitoes. JMedical Entomology 2008, 45(3):439-444. (6)

46. Smith AF, Tsuchida K, Hanneman E, Suzuki TC, Wells MA: Isolation, characterization, and CDNA sequence of two fatty acid-binding proteins from the midgut of Manduca sexta larvae. J Biol Chem 1992, 267(1):380-384.

47. Sridhara S, Bhat JV: Incorporation of [1-14C]acetate into the lipids of the silkworm Bombyx mori L. Biochem J 1964, 91(1):120-3.

48. Sridhara S, Bhat JV: Further Investigations Of The Incorporation Of (114c)Acetate Into The Lipids Of The Silkworm Bombyx Mori L. Biochem J 1965, 94:700-4.

49. Goodman W, Gilbert LI: The hemolymph titer of juvenile hormone binding protein and binding sites during the fourth larval instar of Manduca sexta. Gen Comp Endocrinol 1978, 35(1):27-34.

50. Riddiford LM, Curtis AT, Kiguchi K: Culture of the epidermis of the tobaccohornworm, Manduca sexta [Control by hormones in vitro]. Tissue-Cult-Assoc-Man 1979, 5(1):975-985.

51. Jiang $\mathrm{H}$, Wang $\mathrm{Y}$, Kanost MR: Primary structure of ribosomal proteins $\mathrm{S} 3$ and S7 from Manduca sexta. Insect Mol Biol 1996, 5:31-38.

52. Ausubel FM, Brent R, Kingston RE, Moore DD, Seidman JG, Smith JG, Smith JA, Struhl K: Current protocols in molecular biology. In Current Protocols Greene Publishing Associates Inc and John Wiley \& Sons Inc. New York; 1999:10.7.1-10.8.16

53. SAS: User's quide, Version 8 SAS Institute Inc, Cary, NC; 1999.

doi: $10.1186 / 1472-6793-10-9$

Cite this article as: Kim and Lan, Sterol carrier protein-x gene and effects of sterol carrier protein-2 inhibitors on lipid uptake in Manduca sexta BMC Physiology 2010, 10:9

\section{Submit your next manuscript to BioMed Central} and take full advantage of:

- Convenient online submission

- Thorough peer review

- No space constraints or color figure charges

- Immediate publication on acceptance

- Inclusion in PubMed, CAS, Scopus and Google Scholar

- Research which is freely available for redistribution

Submit your manuscript at www.biomedcentral.com/submit
C) Biomed Central 